\title{
THE LEIOGNATHUS (TELEOSTEI): THEIR SPECIES, STOCKS, AND FISHERIES IN INDONESIA, WITH NOTES OF THE BIOLOGY OF LEIOGNATHUS SPLENDENS (CUVIER)
}

\author{
by \\ DANIEL PAULY ${ }^{1)}$
}

\begin{abstract}
Species of the family Leiognathidac in the Indo-Pacific area are often considered trash fish but are readily accepted in Indonesia, where about 50,000 tons were landed in 1975, 14,000 tons of which originated from the Malacca Strait area. The Western Jawa Sea, Karimata Strait and Indonesia's South China Sea stocks are underfished or, partially, even virgin and production from these stocks might be more than 100,000 tons a year. The leiognathid stocks, having their highest stock densities in very shallow waters (peak at 25 $\mathrm{m}$ depth) are easily overfished by trawling, while the bagan (lift-nets) tend to underfish them. In East Jawa, there is an annual periodicity in the fishery which is correlated with the rainfall, the peak landings being from December through March, while landings are lowest from July to September.

Leiognathus splendens (CUVIER) makes up most of the leiognathid stock ( $90 \%$ and more). The main feature of the biology of this species - growth, reproduction and food are briefly discussed. A short selected bibliography of the Leiognathidae is given.
\end{abstract}

\section{INTRODUCTION}

The species of the family Leiognathidae are close inshore perciform fishes generally not reaching a total length of more than $15 \mathrm{~cm}$. They are represented by about 30 species and distributed over most of the IndoPacific area, ranging from South Africa in the west to Tahiti in the east, and from Australia in the south to Japan and the Red Sea in the north. One species, Leiognathus klunzigeri has entered the Mediterranean via the Suez Canal (Weber \& BeAufort 1931; SMITH 1965; Ben-Tuvia 1966; KuHLMORGEN-Hille 1974). Figure 1 shows the most common species in western Indonesian waters, Leiognathus splendens.

The Leiognathidae form relatively important fisheries. In India, for example, 44,000 tons were landed in 1967, representing almost $6 \%$ of the total Indian marine fish landing (JAMES 1973). In the Philippines 852,000 tons were landed in 1972 (KUHLMORGEN-HILLE 1974). In other countries, such as Malaysia or Thailand, the Leiognathidae, owing to their small size, form the bulk of the "trash fish" and are used for manure, fish meal and

1) Indonesian-German Fisheries Development Project, Semarang, Tromolpos 198. 


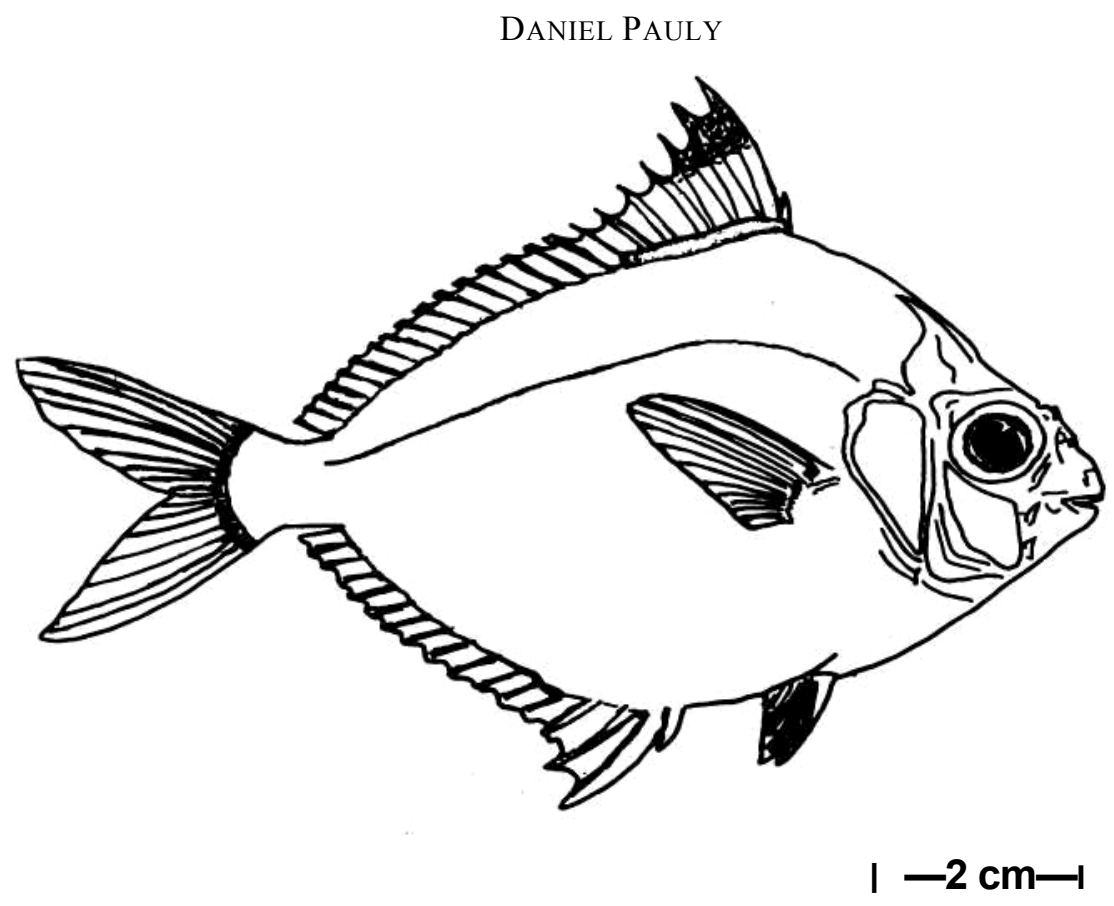

Figure 1. Leiognathus sp lendens (redrawn after DAY, 1878)

duck food. There, only Leiognathus equulus, the only leiognathid species which grows over $15 \mathrm{~cm}$ (reaching up to $26 \mathrm{~cm}$ ) is consumed by man.

Not so in Indonesia. In Jawa especially, all "peperek" are readily accepted and generally fetch a comparatively good price. However, catch and landing statistics generally add the Leiognathidae to the pigeon-hole category of "other fishes". GULLAND (1973) proposed to list them separately under the FAO-name of "slipmouths".

\section{SOURCE AND TREATMENT OF DATA}

The original data presented here have been gathered in the frame of the Indonesian - German Fisheries Development Project which operates a 110 GRT wooden stern trawler, the R/V MUTIARA IV. The gear is a "Thailand Trawl" with a head line length of $36 \mathrm{~m}$ and $40 \mathrm{~mm}$ streched mesh in the cod end.

The areas A, B and C were surveyed between April and December 1975 and a total of 314 sucessful trawl hauls were made. Area D (Malacca Strait) was surveyed from February to March 1975 with 40 sucessful hauls (Fig. 2). 


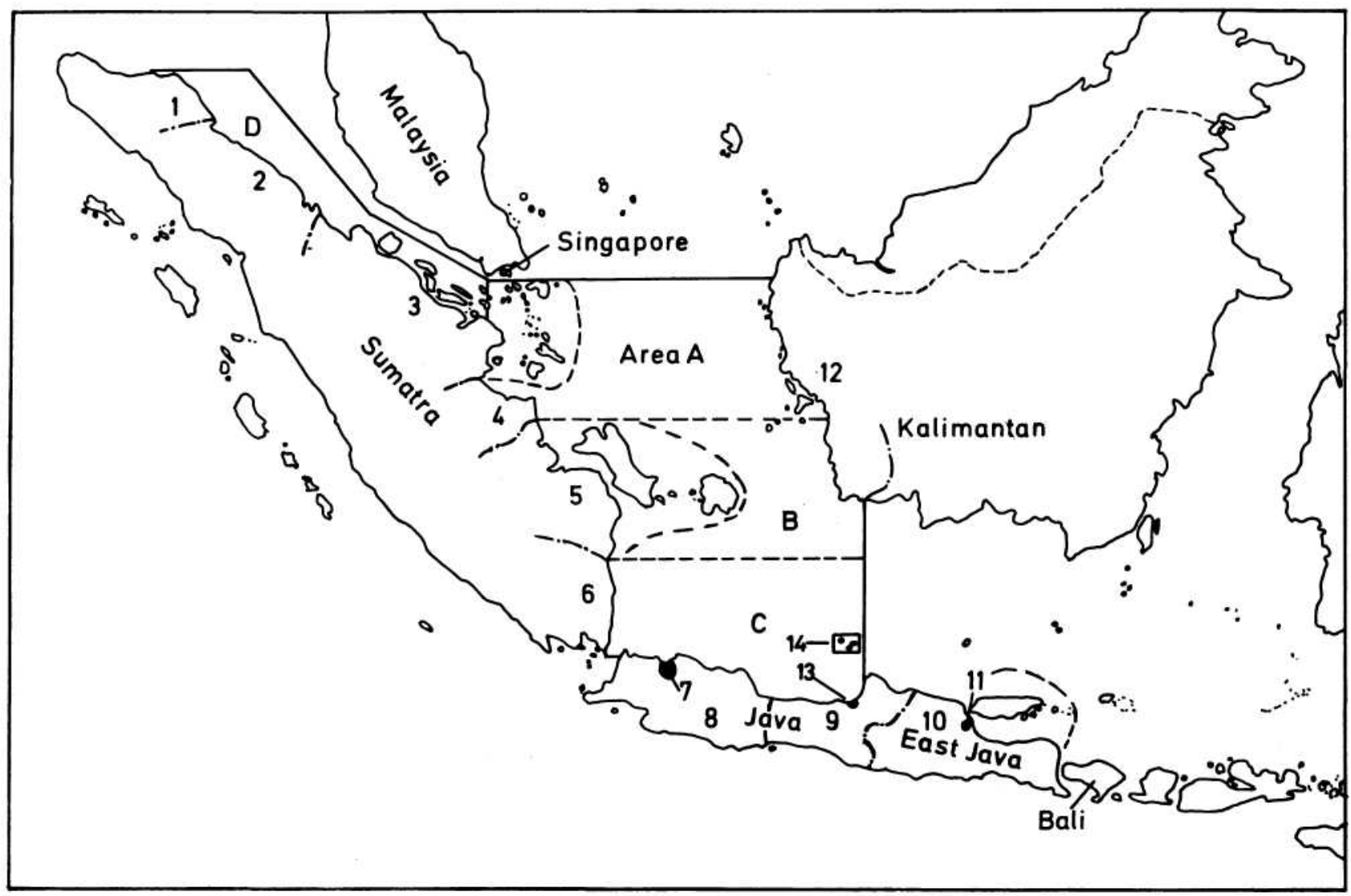

Figure 2. Reference area (Western Indonesia) A: South China Sea, B: Karimata Strait, C: Western Java Sea, D: Malacca Strait, 1: Aceh Province, 2: North Sumatra Province, 3: Riau Province. Other reference number: see table II and text. 


\section{DANIEL PAULY}

A preliminary report of these surveys was presented by JAEGER, MARTOSUBROTO and PAULY (1976). The catch records of the Indonesian research trawlers R/V MUTIARA I and R/V MUTIARA II, which operated in the Malacca Strait in 1973 and made a total of 148 hauls (MARTOSUBRoto 1973) were included in the analyses, as well as the catch records from 12 trawl hauls made in January 1975 by the FAO/UNDP research vessel "LEMURU" in the Malacca Strait area (ANONIMUS 1976). This resulted in a total of 200 bottom trawl hauls for analyses in the Indonesian waters of the Malacca Strait.

The data on effort and catch per unit of effort of the lift-nets and tidal traps in areas $\mathrm{A}, \mathrm{B} \& \mathrm{C}$ were kindly compiled by DR. YAMAMOTO FAO/ UNDP Fisheries Project.

Data on fish species, zooplankton and benthos along the transect line from Semarang (Nr 13 in Fig. 2) to the Karimun Java Islands (Nr. 14 in Fig. 2) were obtained during a two day trial trip of the R/V MUTIARA IV, the 20 and 21 April 1976. The treatment of the samples followed the system adopted in SAEGER et al. (1976). The data were obtained from 8 bottom trawl hauls and contemporary oceanographic stations, which were later pooled to four pairs of two stations each (I-IV).

\section{LEIOGNATHID SPECIES OCCURRING IN INDONESIA}

The last full revision of Leiognathidae from Western Indonesian waters is that by WEBER and BEAUFORT (1931) who recognized 15 species atributed to the genera Leiognathus and Gazza. A 16th species, Leiognathus blochi, which was included in WEBER \& BEAUFORT (1931) because of its occurence in the Philippines and North Borneo has apparently never been recorded from Indonesian waters.

The two genera Genes and Pentaprion were included by WEBER \& BEAUFORT (1931) in the family Leiognathidae. These genera are now placed in the family Gerreidae (GREENWOOD et al 1966). The only full account of the Leiognathidae from eastern Indonesia is that of MUNRO (1967) who recognized the genera Leiognathus, Equulites, Secutor and Gazza from the waters of New Guinea. Leiognathus, as used by WEBER \& BEAUFORT (1931) is now subdivided into Leiognathus and Secutor, while the genus Equulites FOWLER 1964, revived in MUNRO (1967) is placed in the synonymy of Leiognathus (vide KUHLMORGEN-HILLE 1974). Thus, all three valid leiognathid genera occur in Indonesia: Leiognathus LACEPEDE 1803, Gazza RUPPELL 1835 and Secutor GISTEL 1848. 
Of these 15 species, 13 were found during the course of the $\mathrm{R} / \mathrm{V}$ MUTIARA IV surveys, the species not found being $L$. berbis and $L$. dussumieri. L. brevirostris was found quite often in coastal waters of the Jawa Sea, while the 12 other species were listed by WIDODO (1976). Two recently described species from Ambon, Leiognathus hatai and L aureus were not found in the survey area. Their authors' (ABE \& HANEDA 1972) descriptions show that the two species can be referred to Secutor rather than to, Leiognathus. A yet undescribed species, the "Leiognathus sp" which is to be described by KUHLMORGEN-Hille (vide KUHLMORGEN-HILlE 1968, 1974) was found to be fairly common in the shallow waters of Jawa, West and South Kalimantan, as well as in the Riau Archipelago (WIDODO 1976).

Not listed by WEBER \& BEAUfORT (1931) were those leiognathids occuring in New Guinea only. Of these MUNRO (1967) list the following:

Gazzaachlamys JORDAN and STARKS 1917

Equulites novaehollandiae (STEINDACHNER 1879), and

Leiognathus rapsoni MUNRO 1964

Following WEBER \& BEAUFORT (1931), G. achlamys is placed in the synonymy of $G$. minuta, while Equulites is a synonym of Leiognathus. This leaves Leiognathus novaehollandiae and Leiognathus rapsoni as species occuring in eastern Indonesia only. Twenty species of Leiognathidae are thus presently known from Indonesia, including one yet undescribed species. A 


\section{DANIEL PAULY}

short account of the Leiognathidae, with a key and figures for 11 common species was published in Indonesian by HUTOMO (1975).

Site and depth distribution of a virgin stock of leiognathids.

The demersal fish stocks in area A, B \& C (Fig. 2) are presently underexpfoited or virgin stocks, especially in areas A and B. The depth distribution of the leiognathid stock, as derived from the catch rates of the MUTIARA IV in these area should thus roughly reflect that of a virgin stock.

The stock density (d) is determined by the swept area method given by;

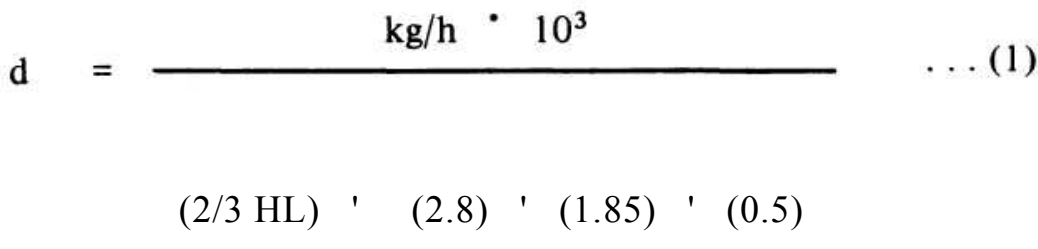

where: 2.8 is the average speed of the R/V MUTIARA IV when trawling, in knots.

1.85 converts knots in $\mathrm{km} / \mathrm{h}$.

0.5 is an estimated value for the catchability factor (SHINDO 1973)

H.L. is the trawl head line, in $m$ (here 36).

As the stock density is directly expressed in ton $/ \mathrm{km}^{2}$, stocks estimates can be obtained by multiplying with the surface area of the area under discussion.

Here, the mean leiognathid stock density was calculated for each depth range (from 0-9 $\mathrm{m}$, to $60-69 \mathrm{~m}$ and $70 \mathrm{~m}$ and more) (Fig. 3), and the density obtained was multiplied with the surface area of the corresponding depth ranges (data from SAEGER et al 1976) and the stocks per depth range added up for the whole of the areas A, B \& C. A total standing stock size of approximately 150,000 tons was calculated for an area of $452,000 \mathrm{~km}^{2}$. This correspond to a mean density of $332 \mathrm{~kg}$ of leiognathid fishes per $\mathrm{km}^{2}$.

Present leiognathid catches from area $A, B \& C$.

The present annual trawl landings from Area A, B \& C might amount to $10,000 \mathrm{t}$, the bulk of which originates from the North Jawa Coast (Area C) (see UNAR 1968). To this, perhaps 5,000 from bagan and related gears should be added.

Potential leiognarhid yield from areas $A, B \& C$.

A rought estimate of the potential yield (Py) of a virgin, or grossly underexploited stock can be obtained by the well-known relations (GULLAND 1968): 
THE LEIOGNATHUS (TELEOSTEI)

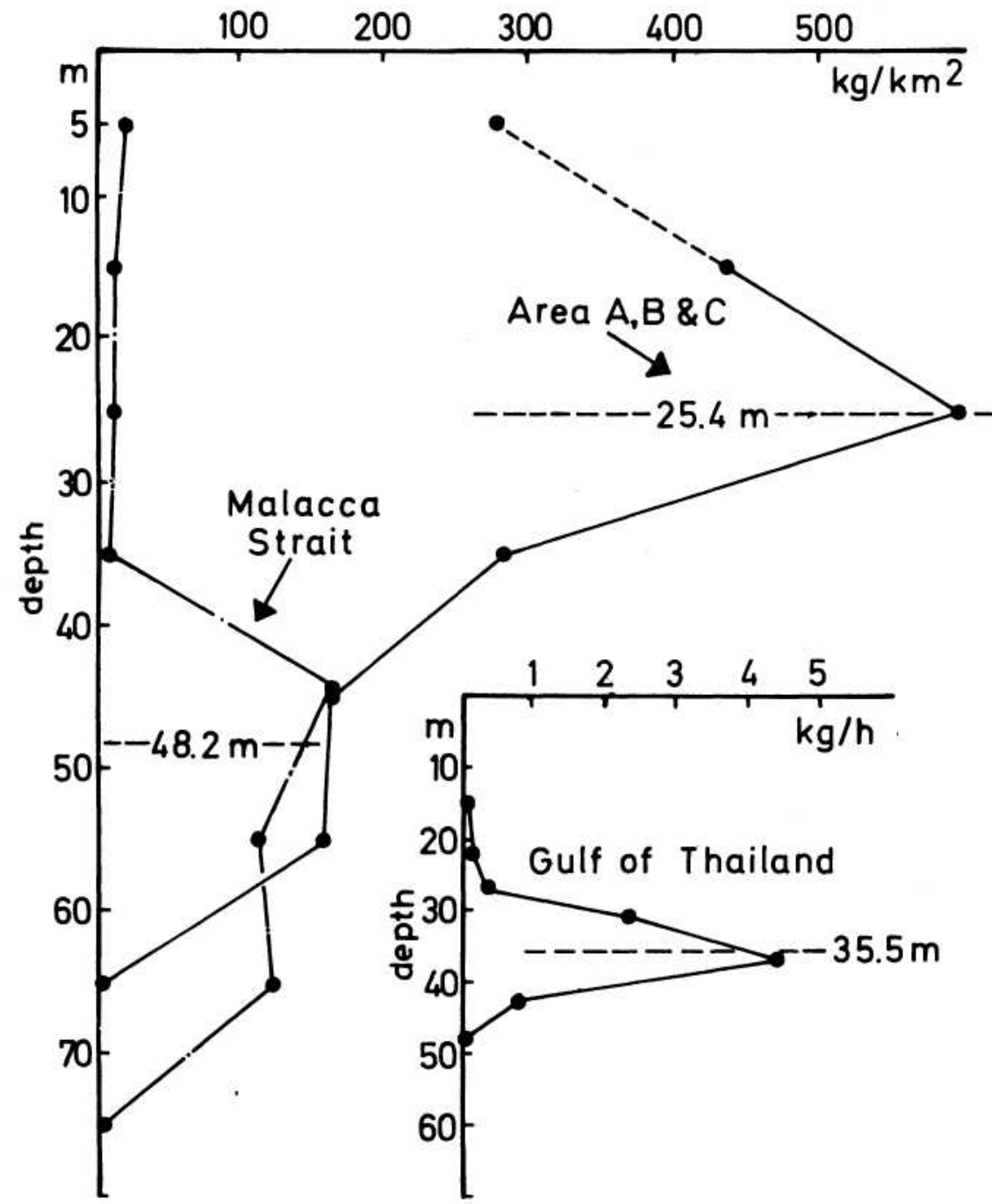

Figure 3. Depth distribution of leiognathid stocks in areas A, B, C \& D and in the Gulf of Thailand. 


\section{DANIEL PAULY}

$$
\mathrm{Py}=0.45^{\prime} \mathrm{M}^{\prime} \mathrm{B} \quad \ldots(2)
$$

where $\mathrm{M}$ is the exponential coefficient of natural mortality, $\mathrm{B}_{\mathrm{o}}$ the standing stock size and 0.45 an empirical constant.

While an estimate of 1.25 as an overal value for $M$ has been derived for demersal fish stocks of the western Sunda Shelf (see SuJASTANI et al 1976) there are presently no estimates of the natural mortality of leiognathid fishes. As a preliminary estimate, a value of 2.0 is used here, which is based on the high rate of growth of Leiognathus splendens, the main contributor to the leiognathid stock.

The potential yield (Py) from Areas A, B \& C is thus:

$$
\text { Py }=0.45 \cdot 2.0 ' 150.000=135.000 \text { tons } / \text { year } \ldots \text {. (3) }
$$

Status of the leiognathid stock in the Malaca Strait as related to the trawl fishery.

Fig. 3 shows the stock density, as related to depth, of the Malacca Strait leiognathid stocks. As trawling is largely limited to the waters shallower than $40 \mathrm{~m}$, it is only this part of the stock which is seriously depleted, as seen by compairing with the situation on area $\mathrm{A}, \mathrm{B} \& \mathrm{C}$, where the mean depth occurence of the stock is $25.4 \mathrm{~m}$. The Malacca Strait stock has its mean depth of occurence at $48.2 \mathrm{~m}$. For comparison, the mean depth occurence was also calculated for the Gulf of Thailand stock, on the basis of data from PHASUK (1965) (Fig. 3). This depth was $35.5 \mathrm{~m}$ in 1962-1963. The mean weighted stock density is much lower in the Malacca Strait than in areas A, B \& C and amounts to $94 \mathrm{~kg} / \mathrm{km}^{2}$ compaired to $332 \mathrm{~kg} / \mathrm{km}^{2}$, while the percentage of Leiognathidae in the total demersal standing stock also is much lower in the Malacca Strait than in areas A, B \& C, amounting to 7.1\% compaired to $13.8 \%$, (see also Table I). This feature is most important as it

Table I. Status of leiognathid stocks in the Malacca Strait and areas A, B \& C 1)

\begin{tabular}{|l|c|c|c|}
\hline \multicolumn{1}{|c|}{ Area } & present standing stock (t) & present landings (t) & sustainable yield (t l \\
\hline Malacca Strait (D) & 5000 & $14000^{2)}$ & $12000^{3)}$ \\
\hline A, B \& C & 150000 & $15000^{4)}$ & 135000 \\
\hline
\end{tabular}

1) Note: 2) from SUJASTANI, MARTOSUBRoto \& PAULY 1976

3) being $85 \%$ of present landings (see SUJASTANI et al, 1976)

4) provisional estimate, based on $M=2.0$, see 4.4. 
means that the leiognathid stocks tend to be depleted faster than the total demersal stock. This is reported also by TIEWS et al. (1967) from the Gulf of Thailand where the average leiognathid catch by the research trawler PRAMONG II in 1966 had dropped to less than $30 \%$ of its 1964 value, while the total demersal stock had dropped to only $53 \%$ of its 1964 value.

The explanation may be that the bulk of leiognathid stocks occur in very shallow waters, where it is more vulnerable to inshore trawling than the overall demersal stock. Another factor is, possibly, the fact that Leiognathids occur over muddy bottoms and in estuaries, in waters generally also yielding shrimps, which attract an overproportionally high number of trawlers. Table I summarize the data on the leiognathid stocks in areas A, B \& C and D (Malacca Strait).

Possible effects of the bagan (lift-net) fishery on a leiognathid stock.

An attempt is presented here to estimate the amount of fish taken by this traditional gear and to estimate its possible effect on a selected fish family. The catch and effort were first plotted in Table II, in which all types of bagan, e.g. the floating and fixed nets, and also the kelongs (tidal traps) of Riau Province are considered to have the same characteristics.

Typically, the bagan consists of a construction of long bamboo poles driven into the sea floor, at a depth up to $15 \mathrm{~m}$, and fitted with a platform from which a large bag-net is lowered and lifted. The unit operates 1 or 2 kerosene lamps, mainly during moonless nights. Three hauls are generally made in one fishing night, the second haul generally yielding $50 \%$ of one nights catch, while the first and third haul share the rest (ARIFIEN 1972). GULLAND (1973) mentions that $60 \%$ of the catch consists of Stolephorus species, a figure also given by ARIFIEN (1972) who investigated bagan catches in the Tangerang area, West of Jakarta. ARIFIEN (1972) reports of a little more than $30 \%$ of leiognathids in the bagan catches. With an estimated 18,000 ton of fish caught yearly by the bagans of areas A, B \& C (Table II) and a figure of $30 \%$ leiognathids, an estimate of 5,400 tons of leiognathids caught yearly by bagan and related gears can be given.

From the stock density values in Fig. 3 and the total surface down to the $15 \mathrm{~m}$ line, which is about $70,000 \mathrm{~km}^{2}$, a total standing stock of $25,000 \mathrm{t}$ of leiognathid was calculated for the potential or actual bagan fishing grounds. From this figure and the appropriate values of equation (3) a potential yield of 22,500 tons of leiognathids can be calculated. Thus, $24 \%$ only of the potentially harvestable leiognathids are taken by bagan and related gears.

ARIFIEN (1972) gives length-frequency data $(n=100)$ for an unindenti- 


\section{Daniel Pauly}

Table II. Stastistical data for bagan (lift-nets) and related gears in areas A, B \& C. ${ }^{\text {a) }}$

\begin{tabular}{|c|c|c|c|c|c|c|c|c|}
\hline 1) & Province & 2) & 3) & 4) & 5) & 6) & 7) & 8) \\
\hline 7 & DKI (Jakarta) & 30 & 100 & 221 & 840 & 3.8 & 7.4 & 1973 \\
\hline 8 & West Jawa & 410 & 37 & 337 & 2337 & 6.2 & 1.2 & 1974 \\
\hline 9 & Central Jawa ${ }^{9}$ & 260 & 68 & 376 & 2256 & 6.0 & 1.4 & 1974 \\
\hline 12 & West Kalimantan & 700 & 84 & 470 & 868 & 1.8 & 0.7 & 1972 \\
\hline 3 & Riau $^{10)}$ & 790 & 55 & 919 & 8087 & 8.8 & 1.2 & 1974 \\
\hline 4 & Jambi & 230 & 100 & 765 & 1087 & 1.4 & 3.3 & 1974 \\
\hline 5 & South Sumatra & 1490 & 100 & 714 & 1508 & 2.1 & 0.5 & 1974 \\
\hline 6 & Lampung & 200 & 35 & 441 & 926 & 2.1 & 2.1 & 1975 \\
\hline & Total & 4110 & & 4283 & 17871 & & & \\
\hline & Mean & & & & & 4.2 & 1.0 & \\
\hline
\end{tabular}

a) Note: 1) Number in fig. 2 .

2) $\mathrm{Km}$ coast line in Area $\mathrm{A}, \mathrm{B} \& \mathrm{C}$

3) Percentage coastline in $\mathrm{A}, \mathrm{B} \& \mathrm{C}$ to total for the province

4) No. of bagans in Area A, B \& C

5) Ton/year from Area $A, B$ \& C

6) Catch/bagan, in tons per year

7) No. of bagan $/ \mathrm{Km}$ coastline

8) year od data

9) Mean from West and East Jawa

10) In Riau Province, the bagans are replaced by "kelongs (tidal traps with weirs and lamps).

fled Leiognathus species caught with bagan from which a mean standard length of $5.5 \mathrm{~cm}$ was calculated. L. splendens and L. equulus, the most common leiognathid species in inshore waters along the Jawa Coast attain first maturity at $7.0 \mathrm{~cm}$ L.st. resp. $17 \mathrm{~cm}$ (ARORA 1952; WALLACE 1975). It would thus seem that most of the bagan leiognathid catch consist of juveniles, a fact known to apply also to other fish groups (GULLAND 1973).

The bagan fishery, while providing work to people and landing sizeable amount of fish thus has serious drawbacks: it underutilizes the stocks and prevents trawling along large parts of the coast. Also, the catch consists mainly of juvenile fish. These aspects will certainly become very important when recruitment to the stocks exploited by the expanding trawl fishery will become a limiting factor.

A similar conflict between an artisanal and trawl fishery, both exploiting the same leiognathid stocks has been discussed by TIEWS and CAECESBORJA (1965).

82 
Annual periodicity of a leiognathid fishery and ecology of some species.

There are few statistical reports which detail monthly landings of Leiognathidae. Here, only those from East Jawa Province, in 1973, were processed. These data were broken down by "Kabupaten" (districts) of which 15 were listed. For each district, the montly percentage in the annual landings was calculated. The data from three districts (Pacitan, Banyuwangi and Bangkalan), each of which had more than one month with zero records, were excluded, as they represented likely cases of underreporting. The monthly percentage of the remaining 12 districts were averaged and the resulting values plotted by month (fig. 4A). It appears that the peak landings occured from December through March, while landings were lowest from July to September. The total landings of leiognathids in East Jawa Province was slightly more than 3 tons in 1973. There is a significant (5\% level) correlation between the monthly landing figures and monthly rainfall in Surabaya, the centrally located capital of East Jawa (fig. 3, No. 11).

The relationship has the equation:

$$
Y=45.3 X-241, r=0.77 \ldots(4)
$$

Where Y is the monthly rainfall in Surabaya in 1973, expressed in mm, and

$\mathrm{X}$ is the percentage of the annual leiognathid landings in 1973 (fig. 4).

Three possible explanations for this phenomenon may be considered:

- $\quad$ fluctations in the fishing effort which are correlated with the rains,

- $\quad$ the fish move out of reach of the gear during the dry season,

- there is a periodicity in the abundance of leiognathids, the latter spawning and rapidly growing during the rain season, during periods of increased fertility in the inshore waters which is due to the increased runoff.

While the latter explanation is probable, it might not be the rain itself which triggers off the spawning activities, but (a) rain induced process (es), such as a reduction of light (clouds) or of water temperature, as shown by WKBER (in press) for a number of tropical marine fishes. As shown in Fig. 5A, the number of leiognathid species decreased rapidly with increasing distance from the coast, increasing transparency and decreasing benthos, the species occuring in deepest water (down to $60 \mathrm{~m}$ ) being L. elongatus and L. bindus. Close inshore species are L. equulus, L. brevirostris, L. splendens, Leiognathus sp. and L daura, while Secutor and Gazza species occur at intermediate depth (PAULY 1976). 


\section{DANIEL PAULY}
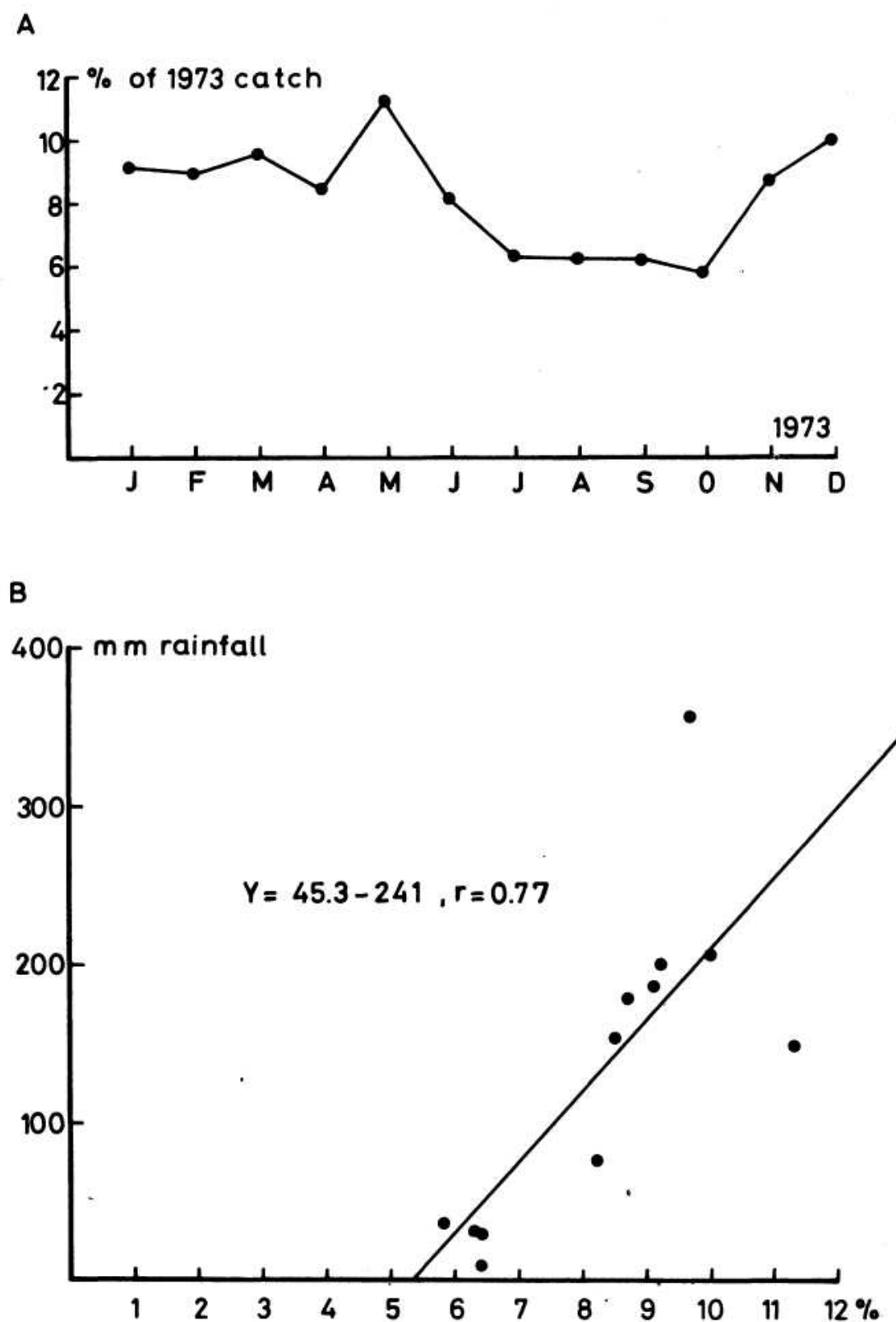

Figure 4. A. Monthly fluctuations of the leiognathid catch, East Jawa Province (1973)

B. Relationship between monthly catch (in percentage of total annual catch) in East Jawa and monthly rainfall in Surabaya (both 1973) 
A
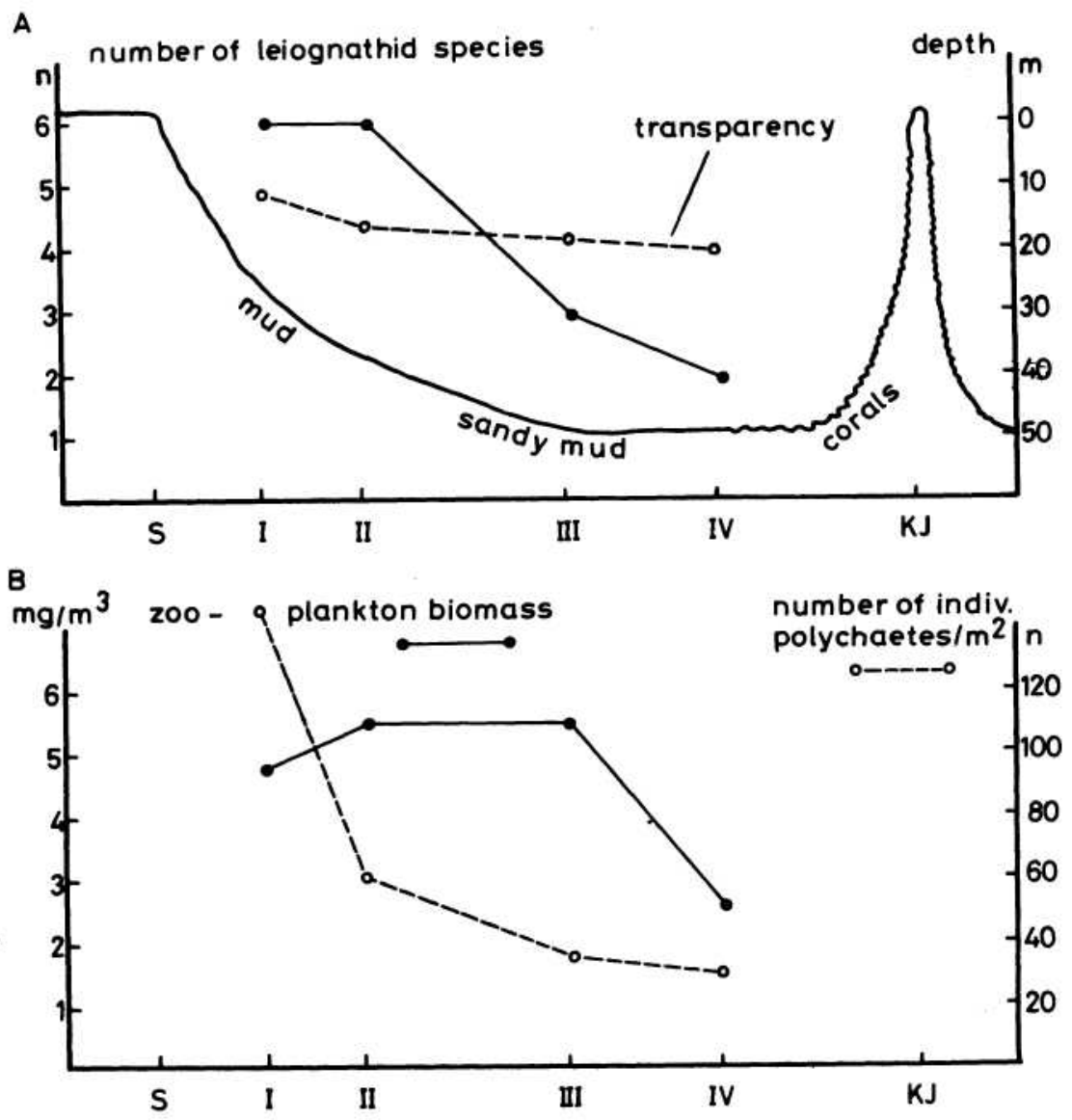

Figure 5. A. Number of leiognathid species and transparency (Secchi-depth) along a transect from Semarang to the Karimun Jawa Islands, April, 1976.

B. Zooplankton and benthic polychaetes along the same transect.

The food of Leiognathus species is mainly benthos (TIEWs et al 1968), with the exception of Leiognathus bindus which, like the Secutor species is zooplanktophagous (CHACKO 1949; BALAN 1967). Gazza minuta is piscivorous and its food consist mainly of young Stolephorus (THAM AH KOW 1950; MANGALIK 1965).

It is therefore the only strong toothed species in a family of weak-toothed fishes. Another interesting feature of Gazza minuta is that this species has by far the heaviest, bulkiest otoliths of the 11 species of Leiognathidae examined by the author. Possibly, G. minuta which hunts its food in a three dimensioned space requires stronger stimuli an its centers of 


\section{DANIEL PAULY}

equilibrium than the other species, most of which forage from the twodimensioned seabottom.

\section{LEIOGNATHUS SPLENDENS}

From the trawling survey in areas A, B \& C (fig. 2) more than 40 hauls yielding leiognathids were sorted to species level. From these, it was determined that $L$ splendens contributes to more than $90 \%$ of the total leiognathid catch. While two species, L. bindus and L. elongatus, tended to occur in more hauls from waters of $40-60 \mathrm{~m}$ depth, a few but large catches of $L$. splendens from these depth still made this species dominate (in terms of weight) in deeper waters. It can, therefore, be stated that a leiognathid fishery in Western Indonesia is essentially a L. splendens fishery. As the combined leiognathid catch in areas A, B \& C represented about $14 \%$ of the total catch, $L$. splendens is possibly the only single species which contributes to more than $10 \%$ of the average catch of trawlers. The notes below briefly review the literature on this important species, mainly in order to show where gaps occur in our knowledge of its biology and ecology.

\section{Taxonomy and systematics.}

L. splendens (CUVIER 1829) was attributed its present generic name by WEBER \& BEAUFORT (1931), who give a complete synonymy. The species seems to be closely related to Leiognathus jonesi JAMES 1969, an Indian species, with which it is easily confused, and also resembles Leiognathus rapsoni MUNRO 1964, which occurs off New Guinea (JAMES 1969; MUNRO 1964). A common english name for this fish is "black tipped pony fish" (MUNRO 1967).

Depth distribution of L. splendens stocks.

The distribution related to depth is shown in figures $6 \mathrm{~A}$ to $\mathrm{C}$. Figure $6 \mathrm{~A}$ is based on 40 hauls sorted to species. The graph closely follows the distribution of the total leiognathid stock (c.f. fig. 3) which is not surprising considering the large proportion of $L$. splendens in the leiognathid catch. Figure $6 \mathrm{~B}$ shows the percentage occurrence of $L$. splendens for each $5 \mathrm{~m}$ depth horizon in a total of 112 hauls found to yield leiognathids, off North Borneo, where the stock similarly to that of area A \& $\mathrm{C}$ can be considered to e virgin (WEBER pers. comm.). Figure $6 \mathrm{C}$ shows the proportion of the catch from various depth horizon in the total L. splendens catch from selected Indian commercial trawl catches (Thusalingam , Venkatamaram \& Krishna KharTA 1968). The three graphs indicate that the commercially 
THE LEIOGNATHUS (TELEOSTEI)

relevant concentrations of $L$ splendens occur at depths of not more than 20-40 $\mathrm{m}$, while isolated shools may occur down to a depth of 40-60 m.
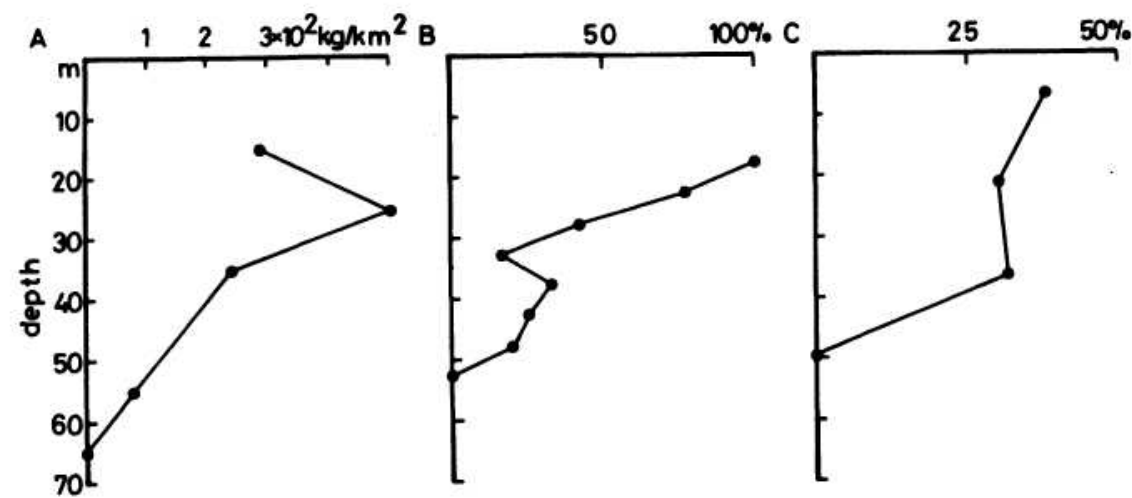

Figure 6. Depth distribution of L. splendens.

A: in Indonesian waters, B: off North Borneo, C: in Indian waters (see text).

Conversions between standard, total and weight.

Table III gives the conversion from standard (L.St.) to total length (L.T.), both in cm, and from total to standard length.

Table III.

L.St.

L.T.

Conversion

\begin{tabular}{|c|c|cc|}
\hline $\mathrm{X}$ & $\mathrm{Y}$ & $\mathrm{Y}=1.22 \mathrm{X}+0.41$ & $\ldots .(5)$ \\
\hline $\mathrm{Y}$ & $\mathrm{X}$ & $\mathrm{Y}=0.80 \mathrm{X}-0.19 \ldots .(6)$ \\
\hline
\end{tabular}

The fishes used for the conversion were trawled in Area $\mathrm{C}$, the range is 7.1 $\mathrm{cm}$ to $14.5 \mathrm{~cm} \mathrm{L.T.,} \mathrm{and} \mathrm{n}=35$.

Table IV gives the conversion from total length, (in $\mathrm{cm}$ ) to weight (in gram), and from weight to total length.

Table IV

\begin{tabular}{|l|c|c|cc|}
\hline form & L.T. & $\mathrm{W}$ & \multicolumn{2}{|c|}{ Conversion } \\
\hline $\log$ & $\mathrm{X}$ & $\mathrm{Y}$ & $\mathrm{Y}=-1.95+3.2166 \mathrm{X}$ & $\ldots . .(7)$ \\
\hline antilog & $\mathrm{X}$ & $\mathrm{Y}$ & $\mathrm{Y}=0.01122 \mathrm{X}^{3.2166}$ & $\ldots .(8)$ \\
\hline $\log$ & $\mathrm{Y}$ & $\mathrm{X}$ & $\mathrm{Y}=0.61+0.381 \mathrm{X}$ & $\ldots(9)$ \\
\hline antilog & $\mathrm{Y}$ & $\mathrm{X}$ & $\mathrm{Y}=4.074 \mathrm{X}^{0.309}$ & $\ldots .(10)$ \\
\hline
\end{tabular}




\section{DANIEL PAULY}

The range was 4.7 to $14.5 \mathrm{~cm} \mathrm{L.T.} \mathrm{and} \mathrm{n}=120$. The exponent $3.216^{\wedge}$ shows that weight growth in L. splendens is allometric.

\section{Growth and natural mortality.}

The growth of leiognathid has apparently never been the object of serious studies. Length frequency data have been published for L. bindus (BALAN 1965), L. equulus (CHABANNE \& PLANTE 1969), 10 leiognathid species, including L. splendens (TIEWS \& CEACES-BORJA 1965) and $L$ splendens (ARORA 1952). The latter author also attempted to interpret his data using the modal class progression method, but apparently connected modal classes which did not represent the same brood. This resulted in an underestimate of both the rate of growth and the asymptotic length (PAULY in prep.). Pending completion of an account of the growth of leiognathids, it may be mentioned here that the asymptotic length (LV) is $13 \mathrm{~cm}$ (L.T.) in L. splendens, with a value for $\mathrm{K}$ (catabolic growth coefficient) of 3.3 (on a yearly basis). This implies that $L$ splendens reaches maturity within less than one year, and that it attains the end of its life-span in 12-14 months. These values, combined with the mean size at first maturity $-9 \mathrm{~cm}$ L.T. - suggest L. splendens has a very high rate of natural mortality. Following CUSHING (1968) it might be assumed that $\mathrm{M} / \mathrm{K}$ is close to unit, hence that $\mathrm{M}$, the exponential coefficient of natural mortality is higher than 3 . The value of $\mathrm{M}=2.0$ used above is thus probably a very conservative estimate. JAMKS (1973) based on similar considerations suggested the Indian leiognathid stocks may be subjected to a very strong fishing effort.

\section{Reproduction}

ARORA (1952) presented in a table fecundity data for 4 length groups based on 12 gonads examined. Here, these length groups have been converted into weight groups by means of equations (5) and (7), the weights being then plotted against the reported average number of mature ova expressed in thousand units. This resulted in a straight line with the equation:

$$
\mathrm{Y}=0.197 \mathrm{X}+4.61, \mathrm{r}=0.955 \quad \ldots\left(\begin{array}{ll}
1 & 1
\end{array}\right)
$$

which is significant at the $5 \%$ level.

Female L. splendens with mature ova were reportedly found over the whole year, with two very strong peaks in March-April and September (ARORA 1952). VANATACHAI (1974) reports April to be the peak time occurence of Leiognathus larvae collected off peninsular Malaysia, near area 
A (Fig. 2). This latter author also gives a detailed description of Leiognathus larvae.

\section{Food and feeding habits}

The food and feeding habits of $L$ splendens have been studied by TiEWs et al. (1968), THAM AH Kow (1950) and MANGALIK (1965). L splendens feeds mainly on benthic animals and plants such as foraminiferans, polychates, ostracods, small decapods and diatoms. Zooplankton, such as copepods and fish eggs from a sizeable part of its diet. L. splendens is reported to belong to those Leiognathus species which consume a relatively greater variety of food items. No difference between the feeding habits of the two sexes was noted (TIEWs et al. 1968). MANGALIK (1965) gives values for the intestinal ratio (length of intestine) ranging between 2.64 and 3.12. standar length

\section{Bioluminescence}

Bioluminescence in Leiognathidae was first reported by HARMS (1928) from specimens of Equula sp. from Pangandaran, West Jawa, and which later were identified as Leiognathus splendens by AHRENS (1967).

HARMS (1928) gave a throughout description of the luminescent gland, associated organs and lightproducing symbiotic bacteria, and reported of observations he made, noteably that the light produced in the dark by $L$. splendens is strong enough to allow reading at close range. For a recent discussion on the character and function of bioluminescence in Leiognathidae see PAULY (1976).

\section{SUMMARY AND DISCUSSION}

The available information shows that the Leiognathidae represent a potentially valuable resource in Indonesia which is fully exploited in the Malacca Strait only. The relatively small size of the present standing stock in that area, as estimated from demersal surveys data, indicate that a very diminished stock can maintain a high production. This feature is best explained by a high natural mortality in the virgin stock.

The leiognathid stocks, however, tend to be more rapidly reduced in size than the total demersal stock of areas where trawling activities are intensive. This is probably due to the occurence of the bulk of these fishes in yery shallow waters, near estuaries and over muddy bottom. Such areas, which often also yield good shrimp catches, generally tend to attract an overproportionate number of trawlers and other gears. 


\section{DANIEL PAULY}

The relationship between leiognathid catches and rainfall, which is common for neritic fishes, needs further investigation as the exact cause (s) of the fluctations is (are) not known yet. The growth and natural mortality of Leiognathus splendens should be studied as the present estimates of these parameters cannot be considered sufficient.

Finally, attention should be given to the migratory patterns and ecological features which determine the location and size of commercially exploitable Leiognathus splendens concentrations. This of special importance, as it appears that in the Java Sea and in the Indonesian Waters of the South China Sea, high catch rates (say $>400$ ) are obtained mainly in areas where $L$ splendens dominates the ichthyofauna in terms of weight.

\section{BIBLIOGRAPHY}

While care was taken to quote most relevant leiognathid references in the text, several references have been added in order to facilitate further studies on lciognathids in Indonesia. Emphasis was given to studies made in adjacent countries and to important studies dealing with the taxonomy, the biology and the fishery, as well as to Indonesian references. The titels with contain no information on Leiognathidae.

ABE, T. and Y. HANEDA 1973. Description of two new species of the pony-fish genus Leiognathus from Indonesia. Sci. Rep. Yokosuka City Mus. 19:1-7.

AHRENS, G. 1965.'Investigations on the light organ of Leiognathus klunzigeri, STEINDACHNER. Z. Wiss. Zool. 173:190-213. (in German).

ALVERSON, D. L.* 1974. Concepts of fisheries development and management strategy. Proc. J.P.F.C 15(3):3 18.

AMARUGSA, C. 1968. Size composition of Leiognathus bindus (VALENCIENNES), L. leuciscus (GUNTHER) and Pentaprion longimanus. Proc. J.P.F.C. 13(2), Australia.

ARORA, H. L. 1952. A contribution to the biology of the silver-belly, Leiognathus splendens (CUVIER). Proc. J.P.F.C 3 (4):75-80.

BALAN, V. 1967. Biology of the silver-belly, Leiognathus bindus (VAL.) of the Calicut Coast. Indian J. Fish. 10A(1):118-134.

BARUS, H. R. 1968. Ikan petek (genus Leiognathus) yang ditangkap dengan trawl di daerah Batang. Thesis Bogor University of Agriculture, Fish. Fac. : 20 pp.

BASHEERUD1N, S. and K. N. NAYAR 1962. A preliminary study of the juvenile fishes of the coastal waters off Madras City. Indian J. F»/r.8(1):162-188.

BEN-TUVlA 1966. Red Sea fishes recently found in the Mediterranean. Copeia 2:254 375.

CHABANNE, J. and R. PLANTE 1969. The benthic populations (endofauna, penaeid shrimps, fishes) of a bight of the north-west coast of Madagascar: ecology, biology and fisheries. Cahier Orstom ser. Ocean 7(1):41-71. (in French).

CHAKO, P. I. 1949. Food and feeding habits of the fishes of the Gulf of Manaar. Proc. Indian A cad. Sci. $29 \mathrm{~B}(3): 83-97$. 
THE LEIOGNATHUS (TELEOSTEI)

CUSHINC, D. H.* 1968. Fisheries Biology: A study in population dynamics. University of Wisconsin Press, Madison, Milwaukee and London: 200 pp.

DAY, F. 1878. The fishes of India. Dawson \& Sons, London: 778 pp + atlas.

DELSMAN, H. C. 1925. Fishes with protusile mouths. Treubia 6:98-106.

DINAS PERIKANAN JAWA TIMUR 1974. Laporan Tahunan 1973.

DKUZHININ, A. and U PHONE HLAING 1968. Observation of the trawl fisheries of South Burma. Proc. J.P.F.C. 13(3): 151209.

DIREKTORAT JENDRAL PERIKANAN 1975. Ketentuan kerja pengumpulan, pengolahan dan penyajian data statistik perikanan. Buku 1, statistik standard perikanan. $207 \mathrm{pp}$.

FAO/SOU IH CHINA SEA FISHERIES DEVELOPMENT PROGRAM 1976. Data and observations by R/V Lemuru cruises 7501 (Jakarta-Belawan, 8-27 Jan. 1975). Workshop on the fisheries resources of the Malacca Strait, Working Paper No. 6:14 pp.

FOWLER, H. W. 1904. A collection of fishes from Sumatra. J. Acad. Nat. Sci. Philadelphia 12(2).

FUJITA 1960. Egg development and prelarval stage of a silver-belly, Leiognathus nuchalis (TEMMINCK\& SCHIEGEL). Bull. Jap. Soc. Sci. Fish. 26(11): 1091-1094.

GREENWOOD, P. H., D. ROSEN, S. WEIZMANN and G. MEYERS 1966. Phyletic studies of teleostcan fishes with provisional classification of living forms. Bull. Am. Mus. Nat. Hist. 131(4):339-456,

HAN EDA, Y. 1950. Luminous organs of fish which emits light indirectly. Pacific Science 4(3):214-227.

HANEDA, Y. and F. J. TSUJI 1972. The luminous organs of two species of Leiognathid fishes recently found in Ambon, Indonesia. Sci. Rep. Yokosuka City Mus. 19:7-11.

HASTINGS, J. W. 1971. Light to hide by: ventral luminous to camouflage the silhouette. Science 173(4001):1016-1017.

HARDENBERG, J. 1931. The fish fauna of the Rokan mouth. Treubia 14(3):299-312.

1937. Observation of fish of the Kumai River. Treubia 16(1):1-14.

1938. Some new or rare fishes of the Indo-Australian Archipelago. Treubia 16(3):311-320.

HUTOMO, M. 1975. Mengenal ikan-ikan laut kita: IV. Ikan petek. Pewarta Oseana 2(4): 1-6.

JAMES, P.S.B.R. 1969. A new species of silver-belly, Leiognathus jonesi (Family Leiognathidac: Pisces) from the Indian Seas. /. Mar. Biol. Ass. India 11(1 \& 2):316-319.

JONES, S. and P. BENDAM 1968. An annotated bibliography on the breeding habits and development of fishes of the Indian region. Central Mar. Fish. Res. Inst. Bull. 3:1-154.

KUHLMORGEN-H1LLET, G. 1968. An illustrated field key to the fish family Leiognathidae in the Gulf of Thailand. Mar. Fish. Lab. Bangkok 12:1-7.

KUHLMORGEN-HILLE, G. 1974. Leiognathidae. in: FAO - Identification sheets for fishery purposes, eastern Indian Ocean (Fishery area 57) and western central Pacific (Fishery area 71). 2. (FISHER, W. and P. J. D. WHITEHEAD eds.) Rome.

KUTHALINGAM, M. 1958. The food and feeding habits of some young silver-bellies. /. Madras Univ. 28B(1): 13-22.

LEMBAGA METEOROLOGI DAN GEOFISIKA 1975. Curah hujan di Indonesia 1973. 


\section{DANIEL PAULY}

LEMBAGA PENELITIAN PERIKANAN LAUT 1972. Survey dengan K.M. Tabularasa th $1971 \quad 1972$.

MANGALIK, A. 1966. Makanan dan tabiat makan dari dua jenis ikan peperek, Leiogiwthus splendens (CUV.), dan Cazza minuta BLEEKER. Thesis Bogor University of Agriculture, Fish. Fac: 30 pp.

MARINE FISHERIES LABORATORY BANGKOK/FISHERIES RESEARCH INSTITUTE MALAYSIA 1967. Results of the joint Thai-Malaysian-German trawling survey off the east coast of the Malay Peninsula, 1967.

MARTOSUBROTO, P. 1973. Mempelajari stok perikanan demersal di Selat Malaka dan Teluk Jambi. Laporan Penelitian Perikanan Laut 1:1-33.

MONKOLPRASIT, S. 1973. The fishes of the leiognathid genus Secutor, with the description of a new species from Thailand. Fish. Res. Bull Kasetart Univ. 6:10-17.

MUNRO, J. S. R. 1955. The marine and freshwater fishes of Ceylon. Dept. External Affairs, Canberra: 351 $\mathrm{pp}$. 16(4):141-186.

1964. Addition to the fish fauna of New Guinea. Papua New Guinea Agr. J. Moresby, New Guinea: $651 \mathrm{pp}$.

PATHANSALI, D., K. S. ONG, S. S. LATIEF and L. J. CARVALHO 1967. Preliminary results of trawling operations off Penang. Proc. J.P.F.C. 12(2): 181-201.

PAULY, D. The Leiognathidae (Teleosts): an hypothesis relating their mean depth occurrence to the intensity of their countershading bioluminescence. (in press).

PAULY, D. On the growth of some fishes of the family Leiognathidae. (manuscript).

PHASUK, B. 1969. A study of demersal catches from the experiment trawlings in the Gulf of Thailand by R/V Fishery Research No. 1 during 1963-1965. Dept. Fish. Publ. 5:151 pp.

PILLAI, M. 1972. Fecundity and spawning of some silver-bellies. Indian J. Fish. 19 (1 \& 2):196-199. FAO, S. 1969. Reproductive cycle and lipid levels in Leiognathus splendens (CUV.). J. Mar. Biol. Ass. India 9(2):303-322.

SAEGER, J., P. MARTOSUBROTO and D. PAULY 1976. First report of the Indonesian-German Demersal Fisheries Project (Results of a trawl survey in the Sunda Shelf Area). Marine Fisheries Research Institute, Spec. Rep.: 1-40.

SHINDO, S. 1973. General review of the trawl fishery and the demersal fish stocks of the South China Sea. FAO Fish. Techn. Pap. 120:49 pp.

SHUNTOV, V. I. 1971. Some data on the biology of fishes of the Arafura Sea and their environmental condition. J. Ichthyology 11(1): 1-8.

SCHUSTER, W. H. 1950. Fish culture in salt water ponds in Jawa. Kementerian Pertanian, Penemuan No. 2, Urusan Perikanan Darat. (in Indonesian).

SCHUSTER, W. H. and R. DJAJADIREDJA 1952. Local common names of Indonesian fishes. Ministry of Agriculture/Laboratory for Inland Fisheries: $176 \mathrm{pp}$.

SMITH, J. L. B. 1965. The sea fishes of sothern Africa. Central News Agency L.T.D., South Africa: 580 pp.

SOEWITO, S. 1961. Pengalaman percobaan jaring tarik di perairan Indonesia. Jawatan Perikanan Laut Pusat, Jakarta. 


\section{THE LEIOGNATHUS (TELEOSTEI)}

SUJASTANI, T., P. MAR IOSUBROTO and D. PAULY 1976. A review of the demersal fishery in the Malacca Strait, as based on recent demersal surveys and catch per effort data. FAO/South China Sea Fish. Dev. Coord. Progr. Workshop on the Fisheries Resources of the Malacca Strait, Working paper No. 1:27 pp.

THAM, A. K. 1950. The food and feeding relationship of the fishes of Singapore Straits. Col. Off. Fish. Publ. 1(1): 1-35.

TIEWS, K. and P. CACES-HORJA 1965. On the availability of fish of the family Leiognathidae LACEPEDE in Manila Bay and San Miguel Bay and on their accessability to controversial fishing gears. Philip. J. Fish. 7(1):59-86.

TIEWS, K., P. SUCONDHARMAN and A. ISARANKURA 1967. On the changes in the abundance of demersal fish stocks in the Gulf of Thailand from 1963/1964 to 1966 on consequence of the trawl fishery development. Mar. Fish. Lab. Bangkok 8:1-39.

TIEWS, K., P. DIVINO, I. A. RONQUILLO and J. MARQUES 1968. On the food and feeding habits of eight species of Leiognathus found in Manila Bay and San Miguel Bay. Proc. Indo. Pac. Fish. Counc. 13 (3): 9399.

UNAR, M. 1968. The "Chantrang" Danish seine fishery of the north coast of Java. Proc. I.P.F.C. 13(3):546553.

UNAR, M., and M. SACHLAN 1958. A list of commersial fishes of Indonesia. Proc. I.P.F.C. 8(2).

VATANACHAI, S. 1972. The identification of fish eggs and larvae obtained from the survey cruises in the South China Sea. Proc. I.P.F.C. 15(3): 111-143.

VENTAKAMARAN, G. I960. Studies on the food and feeding relationships of the inshore fishes off Calicut on the Malabar Coast. Indian J. Fish. 7 (2):275-306.

WALLACE, J. H. 1975. The estuarine fishes of the east coast of South Africa. HI. Reproduction. Ocean Res. Inst. Investigational Rep. 41:1-51.

WEBER, W. The influence of hydrographical factors on the spawning time of tropical fish. In: Proceeding of the international Seminar on Fisheries Resources and their Management in Southeast Asia, West Berlin Nov. 18 - Dec. 7, 1974.

WEBER, M. and L. F. DE BEAUFORT 1931. The fishes of the Indo-Australian Archipelago 6. E. J. Brill, Leiden: $448 \mathrm{pp}$.

WIDODO, J. 1976. A check-list of fishes collected by R/V MUTIARA IV from November 1974 to November 1975. Marine Fisheries Research Institute, Spec. Rep.: 47-77. 